\title{
Impacts of under-canopy vegetation on stand growth in two pine saw-timber stands, South Africa
}

Keith M. Little ${ }^{1 *}$, Carol A. Rolando ${ }^{2}$ and Andrew R. Morris ${ }^{3}$

\begin{abstract}
Background: In pine plantations, shading following canopy closure reduces the growth of competing vegetation. However, canopy closure is not always achieved if low initial planting density, pruning and thinning are practised. This means that complete shading does not occur, resulting in stands with potentially competitive levels of undercanopy vegetation.

Methods: At the time of the first pruning operation, two trials were established to determine the competitive effect of under-canopy vegetation on pine tree growth in South Africa, one on a Pinus patula Schiede ex Schltdl. \& Cham. (4.5 years) and one on a Pinus tecunumanii F.Schwerdtf. ex Eguiluz \& J.P.Perry (2.9 years) stand. This paper documents results at the final thinning operation carried out at 17-18 years. Treatments were weedy (no vegetation control), herbaceous (complete sustained control of woody vegetation), woody (complete sustained control of herbaceous vegetation), weedfree (complete sustained control of all competing vegetation) and operational (only the woody perennial broadleaves were removed prior to any pruning/thinning event in the commercial weed control treatment). From the time vegetation management treatments were first imposed, they were maintained and tree performance monitored over 14-15 successive growing seasons, including and up to the second and final thinning to 250 stems ha ${ }^{-1}$.

Results: The presence of vegetation for up to 15 years had no significant impact on the volume of $P$. patula and P. tecunumanii following two thinning operations ( 813 to 400 stems ha $^{-1} ; 400$ to 250 stems ha $^{-1}$ ). For P. patula, but not $P$. tecunumanii, there was a significant and negative impact of under-canopy vegetation on the total basal area removed during two thinning operations. This may result in a reduction in the selection of stems to remain following thinning, as well as any profit that may be obtained if the thinnings were of commercial value.
\end{abstract}

Conclusions: For the species (P. patula and P. tecunumanii) and sites tested, the results indicate that if good establishment weed control is carried out (from planting until the first pruning event), the development and subsequent impact of under-canopy vegetation over the subsequent 14-15 years (between the first pruning event and the final thinning to 250 stems $\mathrm{ha}^{-1}$ ) on the growth of the remaining stems is negligible.

Keywords: P. patula, P. tecunumanii, Pruning, Selective weed control, Thinning, Weedy, Weedfree

\footnotetext{
* Correspondence: keith.little@mandela.ac.za

${ }^{1}$ Nelson Mandela University, Private Bag X6531, George 6530, South Africa

Full list of author information is available at the end of the article
} 


\section{Background}

Other vegetation growing together with planted 'crop' trees can reduce growth by utilising site resources (water, light and nutrients) that would otherwise be available for tree growth (Richardson, 1996; Little and Rolando, 2001). Most studies to determine the impacts of competitive vegetation on tree growth have been carried out during the establishment phase, typically the period between planting and when canopy closure or 'site capture' occurs (Lauer et al. 1993; Wagner et al. 2006). In most planted forests, reduced light following canopy closure decreases the growth of the competing vegetation and the necessity for further vegetation management (Wagner et al., 1999). Many studies have shown that substantial gains in wood volume can be achieved in response to effective, early control of competitive vegetation (Wagner et al., 2006). For this reason, vegetation management during the establishment of planted forests is considered one of the most important silvicultural practices and is routinely applied to optimise resource availability (Richardson 1993; Miller et al., 2003; Rolando and Little, 2009; McCarthy et al., 2011). Fewer studies have examined the impacts of continuous vegetation control on crop tree growth, or the impact of under-canopy vegetation on final yield, despite undercanopy vegetation occurring in many planted forests.

If canopy closure does not occur, or is delayed, or if shade tolerant vegetation is present at the site, vegetation can continue to develop beneath the canopy as the stand matures (Bredenkamp 1986; Little 2007; Richardson et al. 2002; Albaugh et al. 2012). Situations such as this may occur when the trees are planted at a low density, after pruning or thinning operations, or where the species planted has a low leaf surface area resulting in an increase in the amount of under-canopy light (Harrington and Edwards 1999; Messina and Jenkins 2000; Xiao et al. 2003; Little 2012). A decrease in leaf area due to drought, pest or disease-related leaf senescence (Fujihara et al. 2002) may also facilitate the development of under-canopy vegetation, as will the presence of shade-tolerant, competitive woody species that have the potential to strongly compete with the planted trees (Fortson et al. 1996). On drier sites where under-canopy vegetation persists into mid-rotation, inter-specific competition for water can also occur with resulting impacts on tree growth (Richardson et al. 2002), as could inter-specific competition for limited nutrients, particularly on sites with nutrient deficiencies (Albaugh et al. 2013). Under any of these circumstances, a crop response to under-canopy vegetation control could be expected as the crop and under-canopy vegetation are competing for the same, limited site resources.
Most studies examining the impact of under-canopy vegetation control on stand productivity have been conducted in the USA on intensively managed stands of Pinus taeda L. and Pinus elliotti Engelm. (e.g. Oppenheimer et al., 1989; Clason, 1993; Forston et al., 1996; Caulfield et al., 1999; Williams and Farrish, 2000; Jokela et al., 2010; Albaugh et al., 2012; Liechty and Fristoe, 2013). Many of these stands have a considerable hardwood component, which includes highly competitive species such as sweetgum (Liquidambar styraciflua L.), water oak (Quercus nigra L.), willow oak (Quercus phellos L.), wax-myrtle (Myrica cerifera L.) and bluejack oak (Quercus incana Bartr.). Some of these hardwood species have been shown to negatively impact on final softwood yield, with their removal sometimes contributing to significant gains (Glover and Zutter, 1993; Clason, 1993, Shiver et al., 1994). In contrast, work carried out in South Africa on under-canopy vegetation control in fast-growth, short-rotation eucalypt stands and pine saw-timber stands has, to date, found no impact of under-canopy vegetation, or removal thereof, on planted tree growth (Little, 2002; Little, 2007; Little and Rolando, 2007). These differential responses to removal of undercanopy vegetation are possibly dependent on the type of vegetation that occurs as well as the different mechanisms underlying competition between the planted crop and the under-canopy vegetation.

In South Africa, pine seedlings are planted into sites free of competing vegetation due to the initial benefits of early vegetation control (Little and Rolando 2001; Rolando and Little 2009; Little 2012). The development of any subsequent vegetation is also controlled during the first 3-5 years of growth, after which, reduced light following canopy closure decreases the necessity for further vegetation management. In some pine plantations, however, particularly those planted for saw-timber, full canopy closure is seldom achieved due to repeated pruning and thinning operations resulting in stands with the potential to support high levels of under-canopy vegetation. In 1996/7, two trials were implemented to determine: (i) the effects of under-canopy vegetation on tree growth; and (ii) if there was a competitive influence, at what stage this occurred, in order to establish when vegetation management should recommence. The trials were implemented on a 4.5-year-old Pinus patula Schiede ex Schltdl. \& Cham. and a 2.9-year-old Pinus tecunumanii Eguiluz \& J.P.Perry stand, both located in the summer rainfall region of South Africa. Initial results from these trials at the first thinning operation of 813 to 400 stems $\mathrm{ha}^{-1}$ (12-13 years) were reported on by Little (2007). No significant differences in tree survival or growth were detected at either trial in response to the under-canopy vegetation that developed from canopy closure to first thinning ( \pm 8 years). The trials were continued to determine any impact of the first thinning 
operation (opening of the canopy) on continued development of under-canopy vegetation. This paper documents the results at the second and final thinning operation (from 400 to 250 stems $^{-1}$ ) carried out at $17-18$ years.

\section{Methods}

Both trials were located in KwaZulu-Natal on stands that had been planted for pine saw-timber production. The pines planted were matched to the sites (Morris and Pallett 2000), with P. patula planted at Dargle plantation in the Midlands, and P. tecunumanii at Kwambonambi plantation in Zululand (Table 1). The Dargle and Kwambonambi sites previously supported $P$. patula and $P$. elliottii saw-timber respectively, with the post-harvest residues evenly distributed across the sites at planting. Sites within these regions were chosen, as good establishment vegetation control had been carried out from planting to ensure optimum stocking and tree uniformity. Five treatments were implemented at each site, with treatment initiation timed to coincide with the first pruning event $(1.5 \mathrm{~m}$ lift $)$ which took place at 4.4 years at Dargle and 2.9 years at Kwambonambi.
The five treatments were arranged in a Latin square design at Dargle and replicated six times and laid out in a randomised complete block design (RCBD) at Kwambonambi. At Dargle, each treatment plot consisted of $8 \times 8$ trees $\left(784 \mathrm{~m}^{2}\right)$ with only the inner $4 \times 4$ trees measured, whereas at Kwambonambi each treatment plot consisted of $7 \times 7$ trees $\left(600 \mathrm{~m}^{2}\right)$ with the inner $5 \times 5$ trees measured. The trees were pruned on four occasions at Dargle and on three occasions at Kwambonambi (Table 1).

No competitive vegetation was present on the sites when the trials were initiated, with continued control of all vegetation in the weedfree treatment plots (weedfree). No further weed control was carried out in the weedy treatment plots (weedy), whereas only the woody perennial broadleaved plants were cut and treated prior to any pruning event in the treatment designed to reflect commercial management standards (operational). Selective control of either herbaceous vegetation (grasses and annual broadleaved plants) or perennial woody broadleaved plants was carried out in either the woody or herbaceous treatments, respectively (Table 2). To facilitate harvesting operations as would occur operationally, any woody vegetation in

Table 1 Site characteristics and sequence of silvicultural events in two under-canopy vegetation-control pine trials in South Africa

\begin{tabular}{|c|c|c|c|}
\hline \multirow{2}{*}{\multicolumn{2}{|c|}{ Site information }} & \multicolumn{2}{|l|}{ Trial name } \\
\hline & & Dargle plantation & Kwambonambi plantation \\
\hline \multicolumn{2}{|c|}{ Province and district } & KwaZulu-Natal, Midlands & KwaZulu-Natal, Zululand \\
\hline \multicolumn{2}{|l|}{ Latitude } & $29^{\circ} 33,860^{\prime} \mathrm{S}$ & $28^{\circ} 36.293^{\prime} \mathrm{S}$ \\
\hline \multicolumn{2}{|l|}{ Longitude } & $30^{\circ} 01,404^{\prime} \mathrm{E}$ & $32^{\circ} 11,690^{\prime} \mathrm{E}$ \\
\hline \multirow[t]{3}{*}{ Soil } & Depth (m) & $>1.5$ & $>1.5$ \\
\hline & Texture & Clay ( $6 \%$ sand; $32 \%$ silt; $62 \%$ clay) & Sand ( $92 \%$ sand; $5 \%$ silt; $3 \%$ clay) \\
\hline & Organic carbon (\%) & 5.5 & 0.5 \\
\hline \multicolumn{2}{|c|}{ Elevation ( $m$ a.s.l.) } & 1430 & 40 \\
\hline \multicolumn{2}{|c|}{ Mean annual precipitation (mm) } & 1000 & 1242 \\
\hline \multicolumn{2}{|c|}{ Mean annual temperature $\left({ }^{\circ} \mathrm{C}\right)$} & 15.8 & 21.7 \\
\hline \multicolumn{2}{|c|}{ Climate class } & Cool temperate & Sub-tropical \\
\hline \multicolumn{2}{|c|}{$\begin{array}{l}\text { Site productivity as indicated by the mean top height of all trees remaining } \\
\text { after 2nd thinning }\end{array}$} & $21.5 \mathrm{~m}$ at age 18.3 years & $24.3 \mathrm{~m}$ at age 17.5 years \\
\hline \multicolumn{2}{|c|}{ Species planted } & Pinus patula & Pinus tecunumanii \\
\hline \multicolumn{2}{|c|}{ Date planted } & 15 October 1992 & 15 September 1993 \\
\hline \multicolumn{2}{|c|}{ Planting density } & 813 stems ha ${ }^{-1}(3.5 \mathrm{~m} \times 3.5 \mathrm{~m})$ & 813 stems ha $^{-1}(3.5 \mathrm{~m} \times 3.5 \mathrm{~m})$ \\
\hline \multicolumn{2}{|c|}{ Vegetation management treatments first imposed } & 9 December 1997 & 22 August 1996 \\
\hline \multirow[t]{4}{*}{ Pruning } & 1st pruning (1.5 m lift) & May 1997 & August 1996 \\
\hline & 2nd pruning (3 m lift) & August 1998 & June 1999 \\
\hline & 3rd pruning (5 m lift) & May 2001 & June 2001 \\
\hline & 4th pruning (7 m lift) & March 2003 & - \\
\hline \multirow[t]{2}{*}{ Thinning } & 1st thinning (c. 400 stems ha ${ }^{-1}$ ) & March 2006 (13.2 years) & November 2005 (12.2 years) \\
\hline & 2nd thinning (c. 250 stems ha ${ }^{-1}$ ) & March 2011 (18.3 years) & March 2011 (17.5 years) \\
\hline
\end{tabular}


Table 2 Description of the vegetation-control treatments in two under-canopy pine trials in South Africa. The trials were imposed on trees that had been maintained in a weedfree condition until the first pruning operation

\begin{tabular}{ll}
\hline Treatment & Method description $^{\mathrm{a}}$ \\
\hline 1. Weedfree & All vegetation in treatment plots \\
& controlled with glyphosate \\
& $(\mathrm{N}$-(phosphonomethyl)glycine) \\
& $\left(360 \mathrm{~g}\right.$ a.i. $\mathrm{L}^{-1}$ applied at $\left.4 \mathrm{~L} \mathrm{ha} \mathrm{h}^{-1}\right)$.
\end{tabular}

2. Weedy

No further control of vegetation, except for the slashing of perennial vegetation to facilitate access prior to the two thinning events.

3. Retention of all annual and perennial grasses and annual herbaceous broadleaves (herbaceous)

Selective control of all perennial broadleaves through spot application of triclopyr (3,5,6-trichloro-2-pyridinyloxyacetic acid) $\left(480 \mathrm{~g}\right.$ a.i. $\mathrm{L}^{-1}$ butoxy ethyl ester applied as a $2 \%$ solution) to the cut stumps.

4. Retention of all perennial broadleaves (woody)

5. Operational weed control (operational)

Selective control of all grasses with fluazifop-P-butyl (butyl (2R)-2-[4-[5(trifluoromethyl)pyridin-2-

yl]oxyphenoxy]propanoate) (250 g a.i. $\mathrm{L}^{-1}$ applied at $4 \mathrm{~L} \mathrm{ha}^{-1}$ ). Perennial vegetation slashed prior to the two thinning events to facilitate access.

Perennial vegetation slashed prior any pruning or thinning event, with cut surfaces of woody vegetation treated with triclopyr (480 g a.i. $\mathrm{L}^{-1}$ butoxy ethyl ester applied as a $2 \%$ solution).

${ }^{a}$ Vegetation growth was monitored regularly, with treatments re-imposed annually. Following pruning and/or thinning and where vegetation growth was more vigorous, an additional weeding event was scheduled

all treatments were manually cut (but not treated with any herbicides) prior to the two thinning operations, after which the treatments were re-imposed.

Diameter at breast height (Dbh in $\mathrm{cm}$ ) was measured annually and this, together with the number of surviving trees per treatment plot, was used to calculate basal area (BA in $\mathrm{m}^{2} \mathrm{ha}^{-1}$ ) for each treatment. At Dargle and Kwambonambi, the trees received their first thinning at 13.2 and 12.2 years respectively, where the number of trees was reduced from 813 to a target density of c. 400 stems $\mathrm{ha}^{-1}$. Selection of trees for thinning was based on the removal of those with poor stem form, branch habit and smaller stems. The second and final thinning at 18.3 and 17.5 years (for Dargle and Kwambonambi, respectively) further reduced the stocking from c. 400 to 250 stems $\mathrm{ha}^{-1}$. The selection of trees for removal on this occasion was based on tree form, as well as ensuring the even distribution of remaining trees so as to allow for optimum site resource utilisation. On both occasions, the thinned trees were felled, de-limbed, with only the stem removed from the site.
Analyses of variance (ANOVA), appropriate for either a Latin square or RCBD, were used to test for treatment effects. Only if the $F$ value was significant $(p<0.05)$ were treatment differences further investigated using the least significant difference statistic (LSD). Initial measurements were used as covariates up until the first thinning to correct for any differences between experimental units prior to the start of the trial. In addition, Dbh and BA data prior to and after the first thinning were used as covariates to explain treatment responses over time. However, a reduction in variability across all experimental units due to the removal of smaller diameter trees after the first and second thinnings meant that the use of initial measurements as a covariate no longer had any impact in terms of treatment interpretation and were, therefore, not used in further analyses. The BA removed during the two thinning events was also analysed to determine any significant impacts of treatment on the quantity of small diameter timber removed. For the final measurement, the estimated standing volume per hectare (Vol in $\mathrm{m}^{3} \mathrm{ha}^{-1}$ ) for the different treatment plots was calculated using $\mathrm{Dbh}$, height $(\mathrm{Ht})$ and stocking. Due to the relatively recent introduction of $P$. tecunumanii in South Africa, no volume equation could be found for trees of this size, or age. To allow for a comparison between treatments in terms of volume, a general Schumacher and Hall equation parameterised for $P$. patula was used to estimate volume from stem height and Dbh (Bredenkamp 2000).

Prior to analyses, Bartlett's (Snedcor and Cochran 1956) and Shapiro-Wilk's tests were used to test for homogeneity of variance and normality respectively as these assumptions must be met for a valid ANOVA to be performed. A summary of the results for the analyses of variance both prior to, and after, the final thinning operation is presented in Table 3. All analyses were carried out using GenStat for Windows (VSN International 2013).

Assessments of the under-canopy vegetation occurred prior to the two thinning operations. Biomass samples were taken from three $1-\mathrm{m}^{2}$ quadrats in each treatment plot, dried, weighed and used to estimate above-ground biomass expressed in kilograms per hectare. Although the biomass data were used as covariates to possibly explain any tree growth responses, a lack of significance (treatment responses remained non-significant) meant they were not used in further analyses.

\section{Results and discussion \\ Changes in stocking}

Although the planting density at both trials was 813 stems $\mathrm{ha}^{-1}$, mortality of 6.8 and $9.3 \%$ resulted in a density of 757 and 737 stems ha ${ }^{-1}$ for Dargle and Kwambonambi, respectively, when the treatments 
Table 3 Summary of analyses of variance showing the mean squares for estimated volume before and after the second thinning operation in two under-canopy vegetation control pine trials in South Africa

\begin{tabular}{|c|c|c|c|c|c|c|c|}
\hline \multicolumn{4}{|l|}{ Dargle (P. patula) } & \multicolumn{4}{|c|}{ Kwambonambi (P. tecunumanii) } \\
\hline \multirow[t]{2}{*}{ Source of variation } & \multirow[t]{2}{*}{ df } & \multicolumn{2}{|c|}{ Volume $\left(\mathrm{m}^{3} \mathrm{ha}^{-1}\right)$} & \multirow[t]{2}{*}{ Source of variation } & \multirow[t]{2}{*}{ df } & \multicolumn{2}{|l|}{ Volume $\left(\mathrm{m}^{3} \mathrm{ha}^{-1}\right)$} \\
\hline & & Before thinning & After thinning & & & Before thinning & After thinning \\
\hline Row & 4 & 1346.2 & 669.0 & Rep & 5 & 962.0 & 774.6 \\
\hline Columns & 4 & 1375.3 & 668.5 & Treatment & 4 & $1452.0^{\mathrm{ns}}$ & $776.0^{\text {ns }}$ \\
\hline Treatment & 4 & $900.8^{\text {ns }}$ & $633.8^{\text {ns }}$ & Residual & 20 & 1425.0 & 392.7 \\
\hline Residual & 12 & 974.8 & 611.9 & Total & 29 & & \\
\hline \multirow[t]{2}{*}{ Total } & 24 & & & & & & \\
\hline & Summ & data & & & Summ & data & \\
\hline \multicolumn{2}{|l|}{ Grand mean } & 257.8 & 187.7 & Grand mean & & 321.7 & 251.2 \\
\hline \multicolumn{2}{|c|}{ Coefficient of variation (units) } & 12.1 & 13.2 & \multicolumn{2}{|c|}{ Coefficient of variation (units) } & 11.7 & 7.9 \\
\hline \multicolumn{2}{|c|}{ Standard error of the difference } & 19.8 & 15.7 & \multicolumn{2}{|c|}{ Standard error of the difference } & 21.8 & 11.4 \\
\hline \multicolumn{2}{|c|}{ Shapiro-Wilk test for normality } & $0.94^{\mathrm{ns}}$ & $0.98^{\mathrm{ns}}$ & \multicolumn{2}{|c|}{ Shapiro-Wilk test for normality } & $0.98^{\mathrm{ns}}$ & $0.97^{\mathrm{ns}}$ \\
\hline \multicolumn{2}{|c|}{$\begin{array}{l}\text { Bartlett's test for homogeneity of } \\
\text { variance (Chi-square for } 4 \mathrm{df} \text { ) }\end{array}$} & $2.80^{\mathrm{ns}}$ & $4.11^{\mathrm{ns}}$ & \multicolumn{2}{|c|}{$\begin{array}{l}\text { Bartlett's test for homogeneity of } \\
\text { variance (Chi-square for } 4 \mathrm{df} \text { ) }\end{array}$} & $3.37^{\mathrm{ns}}$ & $2.87^{\mathrm{ns}}$ \\
\hline
\end{tabular}

Note: ${ }^{\text {ns }}$ denotes non-significance

were first imposed. Continued mortality at both Dargle and Kwambonambi resulted in a trial mean of 718 and 704 stems ha $^{-1}$ immediately prior to the first thinning. After the first thinning, 398 stems ha $^{-1}$ remained at Dargle and 374 stems $\mathrm{ha}^{-1}$ at Kwambonambi, representing 48.7 and $45.6 \%$ of the original planting density. The thinning of the trees reduced the BA of the remaining trees by $34.3 \%\left(11.07 \mathrm{~m}^{2} \mathrm{ha}^{-1}\right)$ at Dargle and $35.4 \%$ $\left(14.43 \mathrm{~m}^{2} \mathrm{ha}^{-1}\right)$ at Kwambonambi, with no significant treatment differences detected for the remaining trees at either trial, before or after the first thinning. No mortality occurred between the first and second thinnings at both trials, with a further $28.4 \%\left(8.89 \mathrm{~m}^{2} \mathrm{ha}^{-1}\right)$ and $22 \%$ $\left(7.23 \mathrm{~m}^{2} \mathrm{ha}^{-1}\right)$ reduction in BA following the second thinning at Dargle and Kwambonambi, respectively.

\section{Vegetation growth}

At the time of the first thinning, the biomass of the undercanopy vegetation in the weedy treatment plots at Dargle (13.2 years, $7855 \mathrm{~kg} \mathrm{ha}^{-1}$ ) was greater than that at Kwambonambi $\left(12.2\right.$ years, $\left.1305 \mathrm{~kg} \mathrm{ha}^{-1}\right)$. This was most likely a function of differences in site productivity (Table 1 ) and, as a result, vegetation occurrence. The initial growth of $P$. tecunumanii at Kwambonambi was more rapid, with a mean Dbh of $29.7 \mathrm{~cm}$ at the time of the first thinning (12.2 years). In contrast, the mean Dbh at the time of the first thinning (13.2 years) at Dargle was $25.9 \mathrm{~cm}$. This rapid initial tree growth at Kwambonambi would have increased shading of the under-canopy vegetation as the trees and crown size increased. The weedy treatment plots at Dargle were dominated by woody perennial broadleaves, particularly Solanum mauritianum Scop. and Acacia mearnsii De Wild, with few other species of vegetation recorded. The most predominant woody perennial broadleaves at Kwambonambi were those of Lantana camara L. and Psidium guajava L., with Solanum mauritianum Scop and Melia azedarach L. also present, but less abundant. In addition, the fern Stenochlaena tenuifolia (Desv.) Moore. and various shade-tolerant stoloniferous grasses also occurred in the weedy plots. At both Dargle and Kwambonambi, the ranking of the treatments were the same in terms of vegetation biomass at the first thinning, with the weedy treatment recording the highest, followed by the woody treatment ( 4262 and $1025 \mathrm{~kg} \mathrm{ha}^{-1}$ ), the operational treatment (994 and $562 \mathrm{~kg} \mathrm{ha}^{-1}$ ) and lastly the herbaceous treatment ( 84 and $75 \mathrm{~kg} \mathrm{ha}^{-1}$ ). The reduction in the number of stems from 813 to 400 stems $^{-1}{ }^{-1}$ following the first thinning resulted in an initial increase in understorey vegetation. Prior to the second thinning, the vegetation biomass in the weedy treatment plots at Dargle was $702 \mathrm{~kg} \mathrm{ha}^{-1}$, with a biomass of 407, 361 and $280 \mathrm{~kg} \mathrm{ha}^{-1}$ measured for the operational, woody and herbaceous treatments, respectively. Stem breakage at Kwambonambi, a characteristic of $P$. tecunumanii (Parfitt and van der Sijde 1993) affected $25 \%$ of the remaining trees after the first thinning, and this, together with the presence of more shade-tolerant under-canopy vegetation, created conditions for their continued development (weedy $=3337 \mathrm{~kg} \mathrm{ha}^{-1}$; operational $=3465 \mathrm{~kg} \mathrm{ha}^{-1}$; woody $=1898 \mathrm{~kg} \mathrm{ha}^{-1}$; herbaceous $\left.=1832 \mathrm{~kg} \mathrm{ha}^{-1}\right)$.

\section{Vegetation and thinning impacts on growth of remaining trees}

For both trials, no significant differences were detected between the treatments for BA, before and remaining after the first and second thinning (see Little 2007 for 
results for first thinning), and for Vol, before and after the second thinning (Table 3). However, the significance of the first measurement as a covariate in both trials up until the first thinning (and at only Dargle until the second thinning) indicated that initial growth was possibly a function of initial tree size rather than in response to competitive vegetation. Besides removing trees with poor form, the removal of the smaller diameter stems during the first thinning (and less during the second thinning) further reduced any treatment-related differences and associated variance (Fig. 1).

The lack of a mean tree growth response to the presence of vegetation (woody and/or herbaceous) for 13.9 years at Dargle and 14.6 years at Kwambonambi indicates that the growth of vegetation did not occur at levels which were competitive. This result occurred despite the high vegetation biomass of $7855 \mathrm{~kg} \mathrm{ha}^{-1}$ recorded at Dargle at the time of the first thinning and $3337 \mathrm{~kg} \mathrm{ha}^{-1}$ recorded at Kwambonambi at the time of the second thinning. A similar lack of response in 7-year-old P. patula growth to the mid-rotation control of Rubus cuneifolius Pursh was found by Little and Moodley (2006), and from the under-canopy development (after canopy closure) of vegetation in two shortrotation eucalypt stands (Little and Rolando 2002; Little 2004). In all these studies, the trees were planted into sites free of competing vegetation and maintained in a weed-free state through regular vegetation control until the trees were well established (12-18 months in eucalypts and 3-5 years in pines). Pines are generally deep-rooted trees and at the time of treatment implementation (4.5 years at Dargle and 2.9 years at Kwambonambi), they are likely to have had access to water from lower down in the soil profile than that of the newly establishing vegetation. In a study to examine the response of $P$. taeda and $P$. elliottii to mid-rotation vegetation control and fertiliser across the south-eastern USA, Albaugh et al. (2012) found that the effect of midrotation vegetation control was not related to estimates of competing vegetation basal area, with only 3 out of 13 sites demonstrating a significantly positive volume growth response to vegetation removal for at least one measurement period. This occurred despite the high quantity of competing vegetation basal area that was assessed at some sites (up to $9.6 \mathrm{~m}^{2} \mathrm{ha}^{-1}$ ). Subsequent research indicated that nitrogen use by deciduous competing vegetation could be used to predict pine response to vegetation control in the south-eastern USA (Albaugh 2013). By determining the nitrogen used by competing vegetation, the additional nitrogen available to crop trees after the removal of competing vegetation could account for the level of the growth response observed in the crop (Albaugh et al., 2013). Their predictions did not extend to sites where evergreen species formed the primary competing vegetation. The differences in site nutrition, species planted, competitive vegetation species and growing conditions that occur between South Africa and that of the south-eastern USA make it difficult to compare responses to under-canopy vegetation control across regions. In addition, it is likely that the competing hardwoods in the south-eastern USA are more competitive (for light, water and nutrients) than the perennial
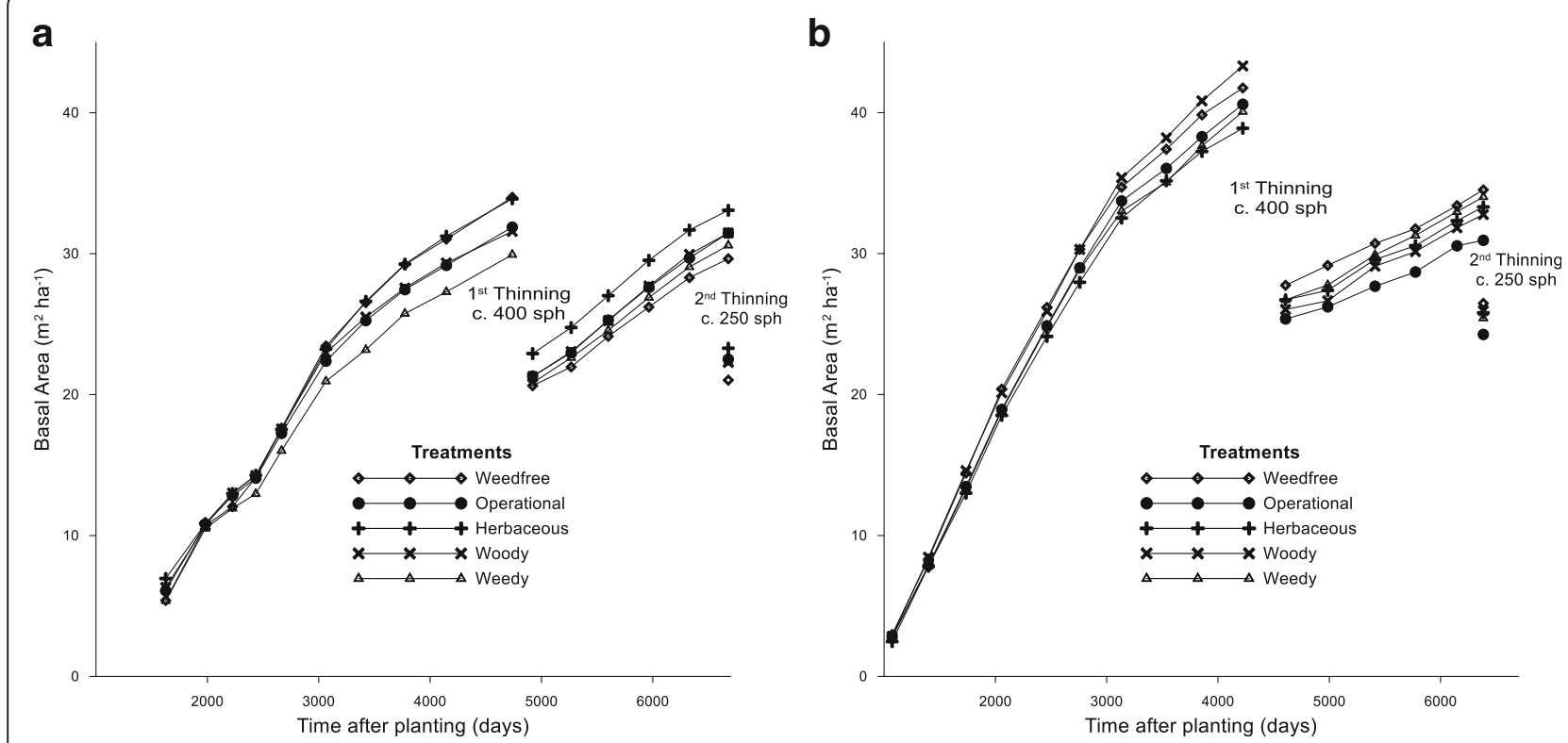

Fig. 1 Changes in basal area (BA; $\mathrm{m}^{2} \mathrm{ha}^{-1}$ ) over time following two thinning operations at a Dargle (P. patula) and $\mathbf{b}$ Kwambonambi (P. tecunumanii), in two under-canopy vegetation control trials implemented in pine stands, South Africa 
broadleaved species that grow beneath the crop canopy in South Africa. It is possible that, in maturing pine plantations in South Africa, competition for nutrients and water between the planted trees and under-canopy vegetation is occurring at different horizons in the stand and therefore, despite high levels of under-canopy vegetation, tree growth is not affected.

\section{Vegetation and thinning impacts on growth of removed trees}

Two thinning operations were carried out in both trials aimed at optimising the value of saw-timber and veneer $\log$ production at clearfelling and were based on standard thinning regimes for the species planted, planting density and different site productivities. Trees removed at thinning are sold for pulpwood, poles and saw logs if they are of suitable dimensions. Even if profit from the first thinning is not the main objective, any income generated may be used to off-set the cost of carrying out the thinning. As such, the influence of vegetation competition on the trees removed during thinning may be of some importance to the land owner. The BA, which is the sum of stem areas of the removed trees, was used to compare between treatments, as well as between thinning events. For both trials, the amount of BA removed was higher at the first thinning than for the second thinning, but the mean $\mathrm{BA}$ removed at the first thinning $\left(16.09 \mathrm{~m}^{2} \mathrm{ha}^{-1}\right)$ at Kwambonambi was higher than that at Dargle $\left(12.35 \mathrm{~m}^{2} \mathrm{ha}^{-1}\right)$ due to the rapid initial growth of P. tecunumanii (Fig. 2).
Significant treatment differences were detected at Kwambonambi $(p=0.038)$ for BA removed at the first thinning, but not for Dargle $(p=0.204)$, with no significance detected at the second thinning for both trials (Kwambonambi: $p=0.767$; Dargle: $p=0.383$ ). At Dargle, there was a general decrease in BA removed at each thinning operation with increased vegetation biomass, with the weedfree and herbaceous treatments significantly higher than the weedy treatment, but not from the operational or woody treatments. This trend remained for those trees removed at the second thinning, resulting in a significant difference $(p=0.026)$ for the total BA removed (sum of BA for both thinnings). However at Kwambonambi, the BA removed did not follow that of the vegetation biomass, possibly due to the limited presence of competition at the first thinning, in combination with non-treatment-related plot variability at the time that the trial was implemented. For both trials, the initial BA measurement when used as a covariate for the first thinning indicated the presence of non-treatmentrelated variability in BA removed which was higher at Kwambonambi $(p=0.004)$ than at Dargle $(p=0.045)$.

Although smaller trees, and those with poor growth form, at the first thinning were removed, the undercanopy vegetation would have competed with trees more when they were 4-12 years old, rather than $12-18$ years when the tree crop would have dominated. Contrasting results were obtained for both trials in terms of the BA removed, however any establishment practices that suppress trees and/or reduce stocking, may potentially
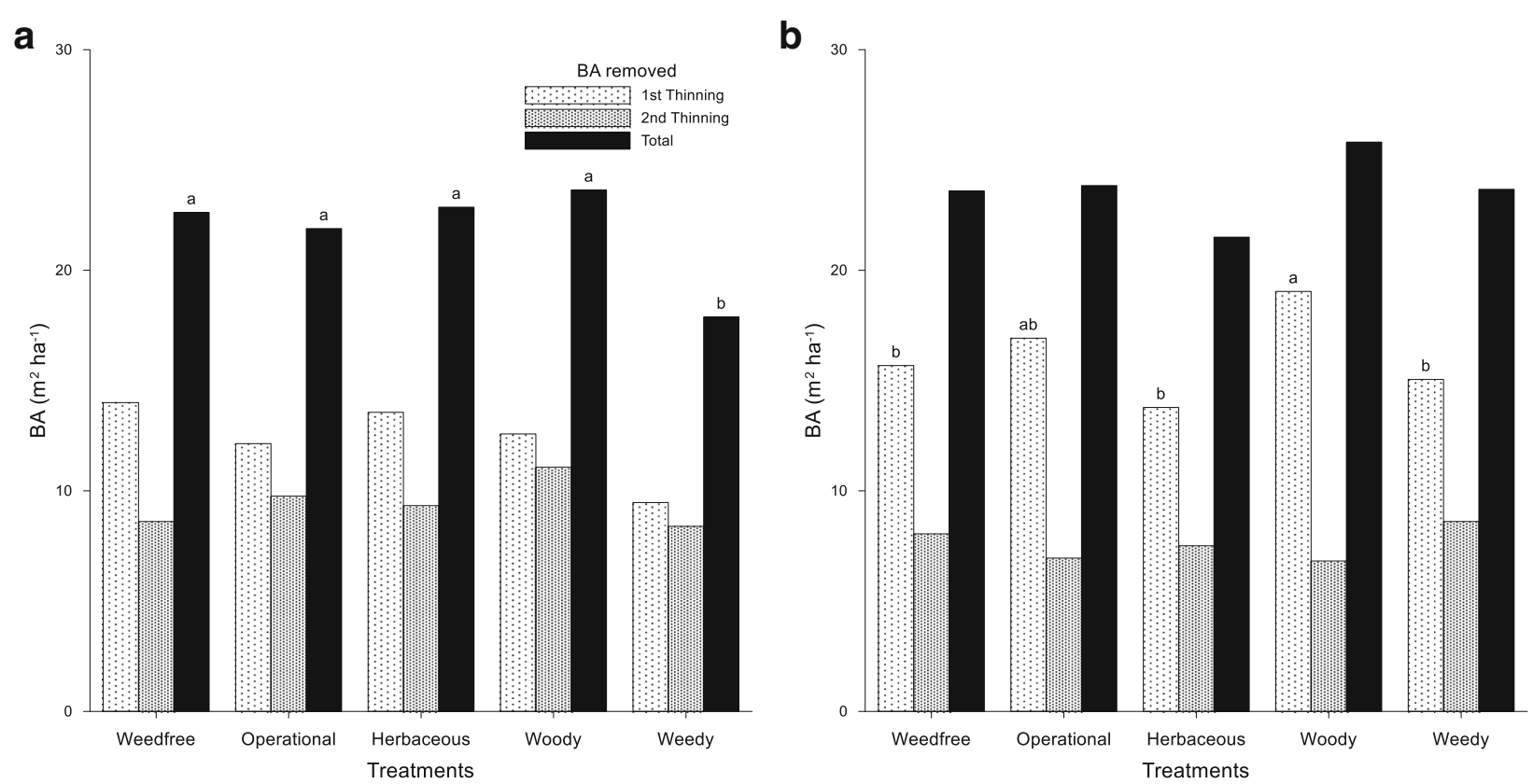

Fig. 2 Basal area (BA; $\mathrm{m}^{2} \mathrm{ha}^{-1}$ ) removed during two thinning operations at a Dargle (P. patula) and b Kwambonambi ( $P$. tecunumanii), in two under-canopy vegetation control trials implemented in pine stands, South Africa 
reduce the BA removed, especially during the first thinning operation. If severe, this will also reduce the number of trees available during the selection process at subsequent thinning operations.

\section{Conclusions}

As the treatments in these trials had limited influence on tree growth, recommendations based on results obtained at the first thinning remained valid through to the second thinning.

The presence of vegetation for up to 15 years had no significant impact on the volume of $P$. patula and $P$. tecunumanii following two thinning operations (813 to 400 stems ha ${ }^{-1} ; 400$ to 250 stems ha ${ }^{-1}$ ). For $P$. patula, but not $P$. tecunumanii, there was a significant and negative impact of under-canopy vegetation on the total basal area removed during two thinning operations. This may result in a reduction in the selection of stems to remain following thinning, as well as any profit that may be obtained if the thinnings were of commercial value. For the species ( $P$. patula and $P$. tecunumanii) and sites tested, the results indicate that if good establishment weed control is carried out (from planting until the first pruning event), the development and subsequent impact of undercanopy vegetation over the subsequent $14-15$ years (between the first pruning event and the final thinning to 250 stems $\mathrm{ha}^{-1}$ ) on the growth of the remaining stems will be negligible. While this is an encouraging result for foresters, it must be acknowledged that on other sites, with other pine species, and where the vegetation spectrum may be different, competition may occur. It is recommended that selective control of woody and invasive plants is carried out where competitive vegetation persists throughout stand development. Control of invasive aliens is required by legislation in South Africa and, therefore, must be carried out and this together with the control of other woody plants will help to:

- Reduce under-canopy fuel loads and risks of uncontrolled fires

- Reduce the seed bank of unwanted vegetation, and prevent their re-establishment

- Improve access for silvicultural and felling operations

- Reduce competition for nutrients on sites where these resources are limiting

Retention of under-canopy vegetation also provides habitat for native birds and ground-dwelling vertebrate and invertebrate species, increasing biodiversity and conservation of native flora and fauna in planted forests (for example Lindenmayer and Hobbs, 2007; Andreu et al., 2008).

\section{Acknowledgements}

The authors would like to acknowledge Singisi Forest Products and SiyaQhubeka for their support and the use of their property. Thanks must also go to all the ICFR technicians involved with these trials, who over the years have helped in their implementation and maintenance.

\section{Funding}

Funding for this research was provided by the South African Forest Industry through Forestry South Africa.

\section{Authors' contributions}

$\mathrm{KL}$ initiated the field trials and all authors contributed to the writing of the paper. All authors read and approved the final manuscript.

\section{Competing interests}

The authors declare they have no competing interests.

\section{Publisher's Note}

Springer Nature remains neutral with regard to jurisdictional claims in published maps and institutional affiliations.

\section{Author details}

${ }^{1}$ Nelson Mandela University, Private Bag X6531, George 6530, South Africa.

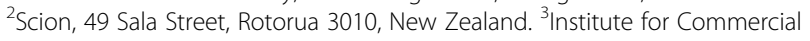
Forestry Research, Box 100281, Scottsville, PO 3209, South Africa.

Received: 13 January 2017 Accepted: 26 December 2017

Published online: 30 January 2018

\section{References}

Albaugh, TJ, Stape, JL, Fox, TR, Rubilar, RA, Allen, HL. (2012). Midrotation vegetation control and fertilization response in Pinus taeda and Pinus elliottii across the southeastern United States. Southern Journal of Applied Forestry, 36(1), 44-53.

Albaugh, TJ, Fox, TR, Blinn, CE, Allen, HL, Rubilar, RA, Stape, JL. (2013). Developing a new foliar nutrient-based method to predict response to competing vegetation control in Pinus taeda. Southern Journal of Applied Forestry, 37(4), 196-201.

Andreu, M, Zobrist, K., \& Hinckle, T. (2008). Management practices to support increased biodiversity in managed loblolly pine plantations. Institute of Food and Agricultural Sciences Extension Document \#FOR183. University of Florida, Gainesville, FL, USA: School of Forest Resources and Conservation Department.

Bredenkamp, BV. (1986). Subtropical ferns do not restrict the growth of pines. South African. Journal of Forestry, 136, 37-38.

Bredenkamp, B (2000). Volume and mass of logs of standing trees. In DL Owen (Ed.), South African Forestry Handbook, (vol. 1, pp. 167-174). Pretoria: V \& R Printers.

Caulfield, JP, Shiver, BD, Pienaar, LV, Quicke, HE. (1999). Estimating financial returns from mid-rotation release in coastal plain loblolly pine plantations. Southern Journal of Applied Forestry, 23(2), 94-99.

Clason, TR. (1993). Hardwood competition reduces loblolly pine plantation productivity. Canadian Journal of Forest Research, 23, 2133-2140.

Fortson, JC, Shiver, BD, Shackelford, L. (1996). Removal of competing vegetation from established loblolly pine plantations increases growth on piedmont and upper coastal plain sites. Southern Journal of Applied Forestry, 20(4), 188-193.

Fujihara, M, Hada, Y, Toyohara, G. (2002). Changes in the stand structure of a pine forest after rapid growth of Queruscus serrata Thunb. Forest Ecology and Management, 170(1/3), 55-65.

Glover, GR, \& Zutter, BR. (1993). Loblolly pine and mixed hardwood stand dynamics for 27 years following chemical, mechanical, and manual site preparation. Canadian Journal of Forest Research, 23(10), 2126-2132.

Harrington, TB, \& Edwards, MB. (1999). Understory vegetation, resource availability, and litterfall responses to pine thinning and woody vegetation control in longleaf pine plantations. Canadian Journal of Forest Research, 29, 1055-1064.

Jokela, EJ, Martin, TA, Vogel, JG. (2010). Twenty-five years of intensive forest management with southern pines: Important lessons learned. Journal of Forestry, 108(7), 338-347. 
Lauer, DK, Glover, GR, Gjerstad, DH. (1993). Comparison of duration and method of herbaceous weed control on loblolly pine response through midrotation. Canadian Journal of Forest Research, 23, 2116-2125.

Liechty, HO, \& Fristoe, C. (2013). Response of midrotation pine stands to fertilizer and herbicide application in the western gulf coastal plain. Southern Journal of Applied Forestry, 37(2), 69-74. https://doi.org/10.5849/sjaf.11-044.

Lindenmayer, DB, \& Hobbs, RJ (2007). Fauna conservation in Australian plantation forests - a review. RIRDC Publication No 05/128. Barton: Rural Industries Research and Development Corporation.

Little, KM (2004). Post-establishment vegetation control in a Eucalyptus grandis stand situated in the KwaZulu-Natal midlands, South Africa. ICFR Bulletin 03/ 2004. Pietermaritzburg: Institute for Commercial Forestry Research.

Little, KM. (2007). Post-establishment vegetation control in two pine saw-timber stands in South Africa. Southern Hemisphere Forestry Journal, 69(1), 59-62.

Little, KM (2012). The interaction between three pine species and weed competition on two contrasting sites in Mpumalanga, South Africa. ICFR Bulletin 04/2012. Pietermaritzburg: Institute for Commercial Forestry Research.

Little, KM, \& Moodley, M (2006). The interaction between seven-year-old Pinus patula trees, competition from Rubus cuneifolius and herbicides in KwaZulu Natal. ICFR Bulletin 10/2006. Pietermaritzburg: Institute for Commercial Forestry Research.

Little, KM, \& Rolando, CA. (2001). The impact of vegetation control on the establishment of pine at four sites in the summer rainfall region of South Africa. Southern African Forestry Journal, 192, 31-39.

Little, KM, \& Rolando, CA. (2002). Post-establishment vegetation control in a Eucalyptus grandis $\times$ E. camaldulensis stand. Southern African Forestry Journal, 193, 77-80.

McCarthy, N, Bentsen, NS, Willoughby, I, Balandier, P. (2011). The state of forest vegetation management in Europe in the 21 st century. European Journal of Forest Research, 1-10.

Messina, MG, \& Jenkins, J. (2000). Loblolly pine stand early development under reserve-tree silvicultural systems in East Texas. Southern Journal of Applied Forestry, 24(1), 11-16.

Miller, JH, Zutter, BR, Zedaker, SM, Edwards, MB, Newbold, RA. (2003). Growth and yield relative to competition for loblolly pine plantations to midrotation-a southeastern United States regional study. Southern Journal of Applied Forestry, 27(4), 237-252.

Morris, AR, \& Pallett, RN (2000). Site requirements and species matching: Pines. In DL Owen (Ed.), South African Forestry Handbook, (vol. 1, 4th ed., pp. 80-84). Pretoria: Southern African Institute of Forestry.

Oppenheimer, MJ, Shiver, BD, Rheney, JW. (1989). Ten-year growth response of midrotation slash pine plantations to control of competing vegetation. Canadian Journal of Forest Research, 19(3), 329-334.

Parfitt, R, \& van der Sijde, HR. (1993). Stem breakage of Pinus tecunumanii in South Africa - a preliminary report. South African Forestry Journal, 167(1), 51-53.

Richardson, B. (1993). Vegetation management practices in plantation forests of Australia and New Zealand. Canadian Journal of Forest Research, 23, 1989-2005.

Richardson, B, Vanner, A, Ray, J, Davenhill, N, Coker, G. (1996). Mechanisms of Pinus radiata growth suppression by some common forest weed species. New Zealand Journal of Forestry Science, 26, 421-437.

Richardson, B, Whitehead, D, McCracken, IJ. (2002). Root-zone water storage and growth of Pinus radiata in the presence of a broom understorey. New Zealand Journal of Forestry Science, 32(2), 208-220.

Rolando, CA, \& Little, KM. (2009). Regional vegetation management standards for commercial pine plantations in South Africa. Southern Forests, 71(3), 187-199.

Shiver, BD, \& Daniel, B (1994). Response and economics of mid-rotation competition control in southern pine plantations. In Proceedings of the 47th Southern Weed Science Society. Raleigh, North Carolina: Southern Weed Science Society.

Snedcor, GW, \& Cochran, WG (1956). Statistical Methods applied to Experiments in Agriculture and Biology, (pp. 265-268). lowa City: The lowa State College Press.

VSN International (2013). GenStat for Windows, (16th ed., ). Hemel Hempstead: VSN International.

Wagner, RG, Mohammed, GH, Noland, TL. (1999). Critical period of interspecific competition for northern conifers associated with herbaceous vegetation. [conference paper]. Canadian Journal of Forest Research, 29(7), 890-897.

Wagner, RG, Little, KM, Richardson, B, McNabb, K. (2006). The role of vegetation management for enhancing productivity of the world's forests. Forestry, 79(1), 57-79.
Williams, RA, \& Farrish, KW. (2000). Response of loblolly pine plantations to late-rotation fertilization and herbicide applications in North Louisiana. Southern Journal of Applied Forestry, 24(3), 166-175.

Xiao, Y, Jokela, EJ, White, TL. (2003). Species differences in crown structure and growth performance of juvenile loblolly and slash pine. Forest Ecology and Management, 174(1), 295-313.

\section{Submit your manuscript to a SpringerOpen ${ }^{\circ}$ journal and benefit from:}

- Convenient online submission

- Rigorous peer review

- Open access: articles freely available online

- High visibility within the field

- Retaining the copyright to your article

Submit your next manuscript at $>$ springeropen.com 